\title{
Tradition-responsive Approach as Non-medical Treatment in Mitigating the Covid-19 Pandemic in Tengger, East Java, Indonesia
}

\author{
Sony Sukmawan ${ }^{1}$, Sahiruddin ${ }^{2}$ \\ \{sony_sukmawan@ub.ac.id ${ }^{1}, \operatorname{shrdn@ub.ac.id^{2}}$ \} \\ Universitas Brawijaya, Indonesia ${ }^{1,2}$
}

\begin{abstract}
Indonesia has inherent various local wisdoms or traditions in response to natural and non-natural disasters. This ethnographic study situating in Tengger village, Pasuruan regency aims at scrutinizing tolak bala (ward off misfortune) ritual, popularly known as nambak lelakon toward Covid-19. The tradition of plague healing inseparable from religious expressions has been assumed having power to double non-medical effort effects toward human physical endurance quality. Thus, nambak lelakon tradition is an effort to maintain and protect human life through collective non-medical mitigation particularly in avoiding the wide spread of Covid-19. The implementation of this tradition is not only part of cultural inheritance passed down from generation to generation through oral tradition (folklore) and a model of shared behavior but also it is mitigation effort toward non-natural disasters. This religious-based tradition is historically of essential to create social collective peace of mind. Nambal lelakon becomes a means of praying with total surrender to God, and it turns out that completely surrendering to God creates peace of mind. Positive thinking effectively reduces anxiety and builds a better mental health.
\end{abstract}

Keywords: Disaster, Folklore, Local Wisdom, Mitigation, Plague, Treatment, Tolak Bala (Ward off Misfortune)

\section{Introduction}

The world is currently experiencing a pandemic, outbreaks of infectious diseases that threaten the safety of humanity. The disease outbreak was introduced by a corona virus, or popularly known as Covid-19. Coronavirus or severe acute respiratory syndrome coronavirus 2 (SARS-CoV-2) is a virus that attacks human respiratory system. Coronavirus can cause disorders of the respiratory system, acute pneumonia, or death. This virus is a new type of corona virus that has historically been transmitted to human. This deadly virus can affect anyone, either baby, children, adults, elderly, pregnant women, as well breastfeeding mothers. Covid-19 was first discovered in the city of Wuhan, China, at the end of December 2019. This virus quickly spread to other regions in China and to many countries in the globe, including to Indonesia.

Taking into an account the increasingly alarming spread of the coronavirus, the Indonesian government declared it as a non-natural national disaster as stipulated in Presidential Decree No. 12 of 2020 on the Stipulation as a Non-Natural National Disaster of the Spread of Corona Virus Disease 2019 (Covid-19). The nature of Covid-19 as non-natural or unnatural disaster is also illustrated by Mostafanezhad [1]. According to the National Disaster Management Agency [2], the coronavirus pandemic is a non-natural disaster, a disaster caused by events or a series 
of non-natural events which include technology failure, modernization failure, epidemic, and disease outbreak. The situation is getting worse making the government issue various policies to reduce the distribution of Covid-19 rates. Such policies are as follows.

The Ministry of Health also released Regulation of the Minister of Health (Permenkes) RI Number 9 of 2020 concerning Large-Scale Social Restriction (LSSR or Pembatasan Sosial Berskala Besar) as guidelines in support of Covid-19 mitigation.

Referring to the Republic of Indonesia's Minister of Health Regulation (Permenkes) No. 9 of 2020, LSSR implementation is to limit certain community activities in an area suspected of being infected with coronavirus disease 2019 (Covid-19) in such a way as to prevent possible more spread to other areas. All policies have been taken by the Indonesian government for the sake of the safety of all Indonesian citizens.

As literally observed, a number of treatments carried out to date have much more focused on medical and physiological health issues. Non-medical and mental health treatments attract less attention both in press releases and in various discussion forums. It is assumed here that non-medical efforts for coronavirus treatment should also play an equally important role to support medical treatments.

In addition to attacking physical health, this virus has also an impact on mental health. Too much exposure to Covid-19 information on a continuous basis regardless of its reliability may likely push people to get more stressed. Physical and psychological effects include intense excessive fear and persistent anxiety about the health condition of oneself and loved ones, and changes in sleep and eating patterns that these all trigger to worsen the existing health condition. Psychiatrists recommend people to stay sane by maintaining inner peace, avoiding excessive panic, and managing stress in the right way. One way to get peace of mental and mind is through meditation and mantra chants. Reporting from the page www.merdeka.com in 2017 that some scientific research actually shows that meditation produces positive benefits, such as patience, self- confidence, happiness, well-being, wise, peaceful mind, and a means of revealing from depression and anxiety or panics.

Beside the practice of meditation, as the interest of this study, the reading of warding off misfortune (tolak bala) ritual can also be practiced. A study showed that, for example, the potential use of reading Ronggosutrasno ballads (kidung) text as to help to cure for diseases and epidemics. It was also evident that the Ronggosutrasno ballad text contained a ritual mantra to cure the disease or free from any disease outbreak. One of them is written in Pupuh Dhangdanggula (1) at 26 and Pupuh Dhangdhanggula (1) at 28. Ronggosutrasno itself is a Javanese manuscript containing a text written by Sunan Kalijaga (one of the most popular Islamic preachers in Indonesia) in collaboration with Ronggosutrasno and later published by Tan Gun Swi. This manuscript is a compilation of several ballads or songs. One type of ballads or songs in the fiber is the Dhandanggula, which means beautiful dreams and hopes. Ronggosutrasno contains magical supernatural powers in the form of mantras and spells which are believed to reject or avoid from any disaster or disease, repellent witchcraft, witchcraft, free from debt, self-defense, ethos of war, ethos of worship, and the system of medicine in Javanese culture. It is not known exactly when it was written, but refers to the biography of the Sunan Kalijaga, this manuscript is thought to have been written around 1500 AD.

In line with the reading of sacred ballad, the prayer is also suggested to be practiced as a way of self-healing and an effort to avoid oneself from disaster. The practice of mantra chants and ballad reading in the family, for example, it is argued that Covid-19 pandemic anxiety can be minimized. The method of family remembrance or dhikr (sort of reciting God's names and attributes) during work from home can be done in a short time after congregational prayer. Dhikr that is done consistently and persistently is a simple remembrance [3]. 
Self-inner peace of mind is indeed very important when dealing with an outbreak of the Covid-19 and the key to avoid stress. Stressful conditions can trigger mental illness and even lead to acute despair so that it pushes someone to do suicide. In the report from CNN Indonesia in 2020, the suicide rate is predicted to continue to rise due to the Covid-19 pandemic. A study of the SARS case in Hong Kong in 2020 found that restricted social interaction, stress and anxiety has caused high suicide rates. In addition, there is a relationship between unemployment and high suicide rates. In this regard, the point about mental health is very fundamental. For this reason, non-medical treatments or efforts are also needed to strengthen medical treatments that have been massively carried out. In addition to meditation, religious rituals and traditional practices can also be considered to mitigate the coronavirus outbreak non-medically. There are various traditional rituals with local wisdom widely practiced in the community, despite the lack of mass-media reporting.

Indonesian has various local wisdom and community-based rituals and activities in handling or mitigating both natural and non-natural disasters in their lives. Communities with local wisdom perform various rituals of tolak bala (warding off misfortune) to prevent various diseases, including the wide spread of coronavirus pandemic. Indonesian society consisting of various tribes has many tolak bala rituals to avoid danger in their lives, as reported by Regional Kompas in 2020 that the community uses cenang (traditional music instrument) which will be hit or kicked if there is a disaster or a disease outbreak. In addition, the Kerinci community in Jambi, for instance, will do Adhan or call to prayer in front of their homes within three days. In contrast, in Solo regency, the mayor and his staff will have their hairs cut (barber ritual) that is believed to be able to resist any disaster or disease outbreak. Likewise, the Rejang Tribe performed a ritual in mitigating non-natural disasters with Kedurei, a ritual characterized by praying to God and honoring ancestors in the Rejang language. The tolak bala ritual was carried out in the middle of rice fields that had not yet been planted. Of course, there are still many kinds of tolak bala rituals that can be described with the aim of revealing each other's potential as a non-medical option against the spread of Covid-19.

This paper specifically presents the discussion about the ritual of tolak bala (warding off misfortune) named nambak lelakon practiced by the Tengger tribe, Probolinggo, East Java, Indonesia. This ritual was chosen for a number of reasons. First, this ritual involves the entire indigenous community so that the impact of its implementation as non-medical aspects is more massive in response to medical aspects. The effectiveness of any practice can certainly be seen from the benefits incurred, and that the nambak lelakon ritual implementation follows the health regulation about the principle of physical distancing. Secondly, Tengger ethnic community is known as one of the ethnic groups who consistently run the tradition in religious package. In more details, Tengger people can live in harmony with diversity which is sustained by a wealth of tradition. Various traditions existed in Tengger is followed by all Tengger residents regardless of social class, religion, and so on. This is because tradition is a culture that also becomes a reinforcement among Tengger people. These traditions are made as a means of meeting between residents so that they are able create harmony between them. Tengger community assumes that tradition can be a space for shaping mutual help, respect, and respect in order to be able creating harmony in all differences. These differences encourage efforts to realize pluralism. Essentially, the Tengger traditional ritual is inseparable from their life. As the Javanese people in general, Tengger community always see the reality of life from two distinct, but not separate, sides. A different reality this must be endeavored to remain in the 'living room'. This cosmic view is reflected in various ways, as in a complete ritual. Rituals in particular always lead to expectations of safety, balance, and harmony throughout aspects of life in the universe. 
The implementation of the tradition of healing from any disease or non-natural disaster along with religious rituals by community is believed to be able to double the non-medical power affecting and improving their physical endurance. Third, the implementation of the tolak bala (warding off misfortune) tradition of the typical Tengger is relatively complete supported by a complex ritual device in terms of form and its meaning. From the complexity of the form of ritual devices (offerings), the nambak lelakon represents traditional knowledge. This tradition reflects the nature of understanding by Tengger community in responding or mitigating the disaster based on the tradition historically followed from generation to generation.

\section{Research Method}

This study is conducted at Tengger village, Tosari district, Pasuruan regency, East Java. The design is qualitative-ethnography as this model explores cultural events presenting human world views as the object of the study [4]. The data of this study are folkloristic expressions used to protect people from any disasters and dangers, particularly in the forms of oral expressions, symbolic behavior, and symbolic materials. Data are collected from resident, shaman priest, staff for shaman priest, and elders who have long been involved in the rituals or tradition.

The procedure of data collection is through unstructured interview and observation. At the first phase, interview is employed as to record oral tradition data by Tengger people in a way that these data are unlikely to be evident in observation [5]. Non-participatory observation is used in this study [6] by observing cultural activities, particularly tolak bala tradition. The collected data are then analyzed ethnographically started from the analysis of social situation data (place, actor, activity), observation and interview, ethnographic interview analysis, domain analysis, structural and contrast interview questions, taxonomy analysis, componential analysis, cultural thematic analysis, and ethnography writing [7].

\section{Findings and Discussion}

\subsection{Various Non-natural Disasters (Plague) in Oral Traditions}

Plague or popularly known as pageblug addressed by the people in Java is one of the various natural disasters that had historically attacked several regions in Indonesia. Javanese people usually start looking for signs or clues or tetenger before an outbreak comes [8]. During the historic Islamic Mataram era, plague has been connected with the arrival of the caudal star or comet or popularly known as lintang kemukus in Javanese tradition. This demonstrates that the appearance of comets in certain directions has its own meaning, one of which is a sign of the arrival of the plague.

In ancient times, there was a plague named lampor which was believed to be an invisible magical creature. However, lampor is not included in the news on TV and only made informed through radio. lampor has the form of a human body butokala (giant) whose head is unlike human's head. His arrival to human life is intended to give a warning for human to continue doing worship to his God with different means. Some Javanese people believe that lampor is a ghost of death, in the form of a fireball. The lampor often makes a noise that came from the 
accompaniment of horses and the pounding of the legs of his soldiers, and in this regard, the people of East Java believe that the arrival of the lampor is to spread an outbreak of disease.

The spread of epidemics and the practice of tolak bala (warding off misfortune) traditions also exists during the Cirebon Islamic Kingdom. The practice of tolak bala (warding off misfortune) is called azan pitu. This tradition exists when royal power in Cirebon is governed by Prince Dipati. This story about the plague that struck Cirebon is passed down over generations happened when Sunan Gunung Djati is still alive with many victims died including Nyi Mas Pakungwati, the grandmother of Prince Dipati himself [9].

\subsection{Nambak Lelakon as a Form of Oral Tradition}

Nambak lelakon is one of the traditions in Tengger that uses offering facilities to request that plague (pageblug/butha kala) is removed without any victim. This ceremony is carried out upon the initiation of dukun pandita as head of religious ritual and tradition which is then agreed by the entire community. Semantically, nambak means "stop", whereas lelakon is a behavior, event, or unexpected event caused by an invisible magical creature, usually called a pageblug, suggesting that nambak lelakon may mean to stop disaster or plague in this context. In one of the Tengger areas, Brang Kulon (area of Tengger in the west side of Bromo mountain, known as Mororejo Village), this tradition is practiced along with the offerings of caru tolak bala and is held at a crossroad in the village.

"As agreed by community, the nambak lelakon ritual in the village was carried out at the village crossroad yesterday. I and other community leaders brought caru tolak bala for ritual offerings. This is a tradition from ancestors. Outbreaks cannot be predicted. It is the will of nature. We have nothing to fight against nature. By means of offerings, we request that butha kala or disaster or outbreak will go away. These offerings are for butha kala so that no victims will be observed" (Romo Sukarji, online interview 5 April 2020).

The control over butha kala using the caru (holy offering) ritual is basically an abstract effort to overcome the disasters caused by spirits [10]. In addition to being carried out formally in the village, nambak lelakon is also carried out personally by a Shaman ritual Pandita in the Widodaren cave and in sanggar pamujan (a place of Hindu meditation) with a set of offerings. The purpose of this personal ritual of tolak bala is to ask for forgiveness from the Creator if there are children from Tengger tribe have made mistakes. However, if the pageblug is the will of nature and God's will, this ritual is an endeavor so that the plague existed does not bring bad effect to human life plans.

"As adat or community leader, I and my staff have done the ritual. This ritual is performed every day within 44 nights at the sanggar pamujan at $23.00 \mathrm{pm}-04.00$ am. Today is the $9^{\text {th }}$ ritual. I have already informed the public, if you want to do this ritual you can do it at home. Offerings are needed at the time of mbukak (opening), namely two plates of jenang abang (brown pudding) and jenang putih (white pudding), one plate of jenang mancawarna (colorful pudding), and one plate of jenang piak/sengkolo (brown and white pudding)" (Romo Puja Pramana, online interview 5 April 2020). 
The Tengger mantra chants or reading in the implementation of nambak lelakon reveal that this tradition is highly related to oral tradition. As a product of oral culture, the oral tradition of nambak lelakon is expressed orally (oral expression) indicated with the use of formulative, additive, aggregative, and redundant-copy patterns. These characteristics are embodied in the structure of mantra, its recitation, context and ritual execution.

"If something odd happens like now, a ritual must be held. Yesterday nambak ritual is to pray that the natural disaster will diminish quickly, and the hope that everybody will be healthy, joyful and prosperous. In the ritual process, the mantra is read sequentially from any type of mantra called as pamenyanan, padupan, prapen, kebaseng, and main mantra or special mantra" (Romo Keto, online interview 10 April 2020).

The sequence of mantra reading starting from the mantra pamenyanan, padupan, prapen, kebaseng (names of general sequences of Tengger ritual), and main mantra is a redundant formula, and this sequence is relatively the same for all condition. In addition, the structure of matra is the same involving opening, remarking Tengger ancestor's names, a designation of intentions and goals, and request for salvation. Even, the sequences of mentioning the ancestors' names are not much different, beginning from mentioning the ruler (danyang) of universe, ruler (danyang) of Tengger mountain, and ruler (danyang) of village. The structure of mantra, recitation and context as well as its ritual execution is a repetition of a formula, through either compilation (agregarit), embedment (aditf), or reasoning (redundan).

\subsection{Nambak Lelakon as Disaster Prevention Practice}

Indonesian society has passed some dynamics of cultural civilization for so long. A culture that contains a number of traditions and religious systems has been automatically selected by the modernization stream, in terms of either being completely diminished or having a modification to remain accepted at all times. It has been observed that cultures evolve along with the changes of modern time [11]. However, among cultures experiencing degradation value of spirituality due to the modernization impacts, there are still many cultures that still exist playing important role in society. One of these traditions is a tolak bala tradition or ritual that is closely related to indigenous Indonesian people. In this regard, in Tengger, this tradition is known as nambak lelakon which aims to protect from the dangers.

"In a current medical term, it is referred to a coronavirus outbreak (Covid-19), but according to the ancients, this term of disease outbreak is named as a pageblug. This ritual (nambak lelakon) is performed to ask for safety to the Almighty. Nambak means to stop, lelakon is something that could not be seen as like a corona virus or pageblug" (Romo Sukarji, online interview 5 April 2020).

Tolak bala is believed as efforts that are traditionally performed to protect from a danger or disaster that will or is happening. The danger, as referred to informant's explanation above, is natural disasters, such as volcanic eruptions, landslides and tsunamis, also non-natural disaster or commonly known as pageblug. Today, the coronavirus pandemic is now experienced by people all over the world, including Indonesia. Pageblug, which in this case refers to a Covid19 pandemic, becomes a shared disaster that must be overcome together. Therefore, indigenous 
people in some regions in Indonesia also showed a proactive response in responding to this outbreak through 'tolak bala' (warding off misfortune) ritual.

In addition to technical-practical and medical efforts undertaken to prevent the spread of this virus to Tengger area Tanah Hila-Hila, a series of traditional rituals are also carried out. Nambak lelakon is a repressive effort taken by Tengger society to stop or diminish the invisible thing, like pageblug, at Tengger area. In fact, Nambak lelakon can be executed by all Tengger society. However, the current pandemic situation does not allow the society to perform ritual simultaneously in the old shrine (Sanggar Pamujan), so that it is only carried out by traditional folks, namely Dukun, Sepuh, and Legen. Meanwhile, people can still do this ritual in their homes by asking God to give them a healthy (seger waras) and wish that the coronavirus pandemic (pageblug) will go away as soon as possible.

Besides, the ritual nambak lelakon carried out by the Tengger tribe is based on the belief that the life cycle does not only exist on a scale nature, but also on a non-scale nature. This invisible non-scale life is believed to have supernatural powers in a sense that if their existence is disturbed, it will cause damage to life order of scale nature. These powers are personified as named or non-anonymous spirits, in which their existence can be understandable. Both are believed to co-exist one another, so that in terms of the relationship between scale nature and non-scale nature, humans must be proactive in building or maintaining a harmonious relation between them [12].

"This ritual aims to return (pandemic) to its origin. So, if the virus is originally from east (wetan), it is expected that the virus will get back to east (wetan) where it is originated, and the same pray also hopes that if the virus is originally from south (kidul), it will get back to south (kidul). The virus is expected to get rid of our area. So, it is believed that if we want to get the virus get back to its origin, we have to give it an offering (sangu) so that the virus will not disturb the children or people here any longer. Therefore, through offering (sesajen) we wish that butha kala will quickly go away and will not have any victim" (Romo Sukarji, online interview 5 April 2020).

Referring to Tengger's cosmology, butha kala is defined as a representation of all forms of negativity, including pageblug. More explanation about the Tengger community's (wong Tengger) paradigm is explained, particularly in defining bhuta kala as referring to both supernatural creature or spirits and a disaster [13]. In this case, the Covid-19 phenomenon can be regarded as a representation of bhuta kala. Through the ritual of the nambak lelakon, it is hoped that the deadly coronavirus pandemic as a manifestation of butha kala will soon go away.

\subsection{Nambak Lelakon as Rituals for Revealing from Depression}

One of the efforts to mitigate the Covid-19 outbreak is through means of spirituality. The use of spirituality as a method of mitigating Covid-19 pandemic seems to bring real contribution to community regardless its lack of implementation and mass- media reports. The contribution can be defined in terms of educating social mental health including inner peace of mind and revealing from anxiety during this pandemic condition. This non-medical method can be applied in medical world to develop mental health. The non-medical mitigation of coronavirus condition through the power of positive thinking by relying totally to God (mindset ilahiah) can be performed. 
Furthermore, soul or mental purification through the Sufism method can be used to make a real contribution to deal with Covid-19 pandemic [14]. The application of this method is both preventive in nature for the health people and curative for people who are categorized as People under Surveilance (Orang dalam Pengawasan/ODP) and Patients under Supervision (Pasien dalam Pengawasan/PDP). In practice, people's mental will be healthy if their mind is trained to concentrate through correct breathing technique and proper behavior and attitude in response to coronavirus pandemic.

The creation of inner peace or peace of mind is one of the main objectives from the implementation of all Tengger rituals, including the implementation of rituals nambak lelakon. The local people believe that if they do not conduct the rituals, Dewata or God will be angry and in turns humans themselves will suffer from punishments and disasters. Simply put, by carrying out rituals, they have the state of psychological or spiritual calm allowing them feeling peace in performing their daily lives, including carrying out daily routine work in the fields. The implementation of religious rituals is believed to be able to generate inner peace. Furthermore, religious awareness is a solution in dealing with problems people meet in their lives. In addition, various formal and informal religious ceremonies that anthropologically forming normative spirituality are caused by the same need for inner peace and theological solutions to existing problems [15].

The Tengger communal ceremony particularly (selametan) is always equipped with a set of offerings (sesaji). The delivery of offerings (sesaji) at every ritual activity guarantees a comfortable life for human. It is confirmed that the comfort of working in harmony with nature was only found and felt by Javanese society, including the Tengger, after conducting rituals to foster harmonious relationships with ancestral spirits through the preparation of offerings (sesaji) and communal ceremony (selametan) [16].

Communal ceremony or feast (selametan) refers to the values of equality, harmony, happiness and prosperity aiming at achieving the safety and both physical and mental happiness [17]. The actual function of ritual practice (communal ceremony) is upholding moral values in which human and nature should have a harmonious and peaceful relation [18]. Harmony and peacefulness can be obtained from the ritual practices including tolak bala (warding off misfortune). In this case, the ritual practice becomes an instrument of soul purification. The essence of mental cleansing is a tranquility. It is argued that mental cleansing can be performed through doing correct breathing, calming the mind, and managing good attitude [19].

One of the efforts to seek peace of mind is through the meditation in Widodaren cave, full attention by listening to mantra chants by dukun pandita as a head of religious ritual and tradition, and full concentration toward the rituals either from the real location or from home. The most important message of this process of mental cleansing through this ritual is the rise of optimism and strong positive hope that butha kala and the outbreak will soon go away from their lives. This hope and optimism will reduce excessive anxiety within individual and society, including the anxiety to get infected by Covid-19, both in terms of temporary anxiety (state anxiety) and permanent anxiety (trait anxiety) [20]. Temporary anxiety will trigger permanent anxiety attract so that psychosomatic disorder is inevitable. People are in need of replacing negative feelings to positive ones by always trying to cleanse themselves and carry out total resignation (complete surrender toward God) [21]. This resignation can be achieved through the implementation of nambak lelakon ritual as in Tengger. 


\section{Conclusion}

The study of oral tradition tolak bala has a strategic value, not merely as a reflection of historical significance toward historical events in the past, but also an introspection in managing the soul for a more peaceful life. The practice of this tradition also implicitly expresses the role of social awareness and social cooperation in finding out the solutions to preserve life and protect humanity. In the current context, the nambak lelakon tradition and other traditions of tolak bala are human collective efforts to preserve life and protect humanity through nonmedical efforts to prevent the spread of the Covid-19. The tradition of tolak bala is not merely historical facts transmitted orally from generation to generation but also a community practice currently implemented from generation to generation. The implementation of this tradition is one of the mitigation efforts for non-natural disaster. This tradition which is mainly based on religion is needed in the pursuit of social collective peaceful mind. The excessive anxiety due to Covid-19 pandemic can be alleviated by turning it into optimism and a strong belief that a pandemic could soon be overcome. The ritual of tolak bala becomes a means of total resignation or submission to the will of God and getting closer to God. With total submission to God will allow human to overcome anxiety and worry. Positive thoughts can bring optimism and reduce or control anxiety so that the quality of mental health can be achieved.

\section{References}

[1] M. Mostafanezhad, "Covid-19 is an unnatural disaster: Hope in revelatory moments of crisis," Tour. Geogr., vol. 22, no. 3, pp. 639-645, 2020.

[2] Badan Nasional Penanggulangan Bencana, "Definisi Bencana," Badan Nasional Penanggulangan Bencana, 2020. [Online]. Available: https://bnpb.go.id/definisi-bencana.

[3] M. Abdullah, "Menolak Wabah dalam Serat Ronggo Sutrasno Karya Sunan Kalijaga," Nusa J. Ilmu Bhs. dan Sastra, vol. 15, no. 1, pp. 118-133.

[4] U. Ulfiah, N. K. N Kardinah, F. Hikmawati, and U. Rohman, "Metode zikir sebagai upaya keluarga dalam menghadapi kecemasan pandemi Covid-19," LP2M, 2020.

[5] S. Endraswara, "Metode Penelitian Kebudayaan," Gadjah Mada, 2006.

[6] S. Y. Sudikan, Metode penelitian kebudayaan. Unesa Unipress, 2001.

[7] P. Suparlan, "Metode penelitian kualitatif," Progr. Kaji. Wil. Amerika Progr. Pascasarj. Univ. Indones. Jakarta, 1994.

[8] J. P. Spradley, M. Z. Elizabeth, and Amirudin, Metode etnografi. Tiara Wacana Yogya, 1997.

[9] R. H. Putri, "Mitos dan Tetenger Wabah Penyakit," Historia, 2020. [Online]. Available: https://historia.id/kultur/articles/mitos-dan-tetenger-wabah-penyakit-DEnRa.

[10] D. Kahmad, W. Hernawan, T. Zakaria, and T. F. Sari, "Ritual Azan Pitu sebagai upaya mencegah penyebaran wabah Covid-19 di Cirebon," Karya Tulis Ilm. Dosen UIN Sunan Gunung Djati Bandung.

[11] D. N. A. Sudiarhti, "Pemaknaan Mitos Bhuta Kala dalam Tradisi Ogoh-Ogoh Sebagai Media Pendidikan: Suatu Kajian Pustaka,” J. Wacana Sar., vol. 19, no. 1, p. 2, 2019.

[12] L. M. Bauto, "Perspektif Agama Dan Kebudayaan Dalam Kehidupan Masyarakat Indonesia," J. Pendidik. Ilmu Sos., vol. 23, no. 2, 2014.

[13] S. Sukmawan, M. S. Rizal, and M. A. Nurmansyah, Green folklore. Universitas Brawijaya Press, 2018.

[14] F. Rahmi, "Folklor Unan-Unan Tengger: Kajian Ekokritik.” Universitas Brawijaya, 2019.

[15] N. Naan, Y. Yumna, and A. Adnan, "Kontribusi sufisme di bidang kesehatan jiwa dalam menghadapi Covid-19," LP2M, 2020.

[16] B. A. Saebani, M. Nadjib, M. Kamal, and Y. Sutiana, "Kesadaran teologis keberagamaan umat manusia dalam menghadapi wabah Covid-19," Digit. Libr. UIN Sunan Gunung Djati Bandung, 
2020.

[17] S. Sukmawan, Sastra Lingkungan: Sastra Lisan Jawa dalam Perspektif Ekokritik Sastra. Universitas Brawijaya Press, 2015.

[18] L. S. Triyoga, Merapi dan orang Jawa. Gramedia Widiasarana, 2010.

[19] E. Durkheim and J. W. Swain, The elementary forms of the religious life. Courier Corporation, 2008

[20] H. I. Khan, Dimensi Spiritual dalam Psikologi. Bandung: Pustaka Hidayah, 2020.

[21] A. Meiza, D. Puspasari, and N. Kardinah, "Kontribusi Gratitude Dan Anxiety Terhadap Spiritual Well-Being Pada Orang Tua Anak Berkebutuhan Khusus," Humanit. J. Psikol. Indones., vol. 15, no. 1 , p. $267232,2018$. 